\title{
Segmentation of the Wild Animal Meat Consumer Market in Belém Municipality, Pará State, Brazilian
}

\section{Amazon}

\author{
Fabrício Khoury Rebello \\ $\mathrm{PhD}$ in Agrarian Science, Professor, Federal Rural University of the Amazon, PO Box
}

917, Belém, Pará, Brazil

Paula Cristiane Trindade Gonçalves

Master in Agroecology, Federal University of Viçosa, Viçosa, Minas Gerais, Brazil

\section{Carina Chagas Madeira de Souza}

Master in Agronomy, Federal Rural University of the Amazon, Belém, Pará, Brazil

Marcos Antônio Souza dos Santos (Corresponding author)

$\mathrm{PhD}$ in Animal Science, Professor, Federal Rural University of the Amazon, PO Box 917, Belém, Pará, Brazil, E-mail: marcos.marituba@gmail.com

\section{Andréia Santana Bezerra}

Master in Health and Animal Production, Federal University of Pará, Castanhal, Pará, Brazil

\section{Bruno Cabral Soares}

$\mathrm{PhD}$ in Animal Science, Professor, Federal Rural University of the Amazon, Paragominas, Pará, Brazil

\section{Maria Lúcia Bahia Lopes}

PhD in Applied Economics, Professor, Federal University of the Amazon, Belém, Pará, Brazil 
João Paulo Borges de Loureiro

Master in Health and Animal Production, Professor, Federal Rural University of the Amazon, Parauapebas, Pará, Brazil

Received: October 12, 2021 Accepted: February 18, 2022 Published: March 6, 2022

doi:10.5296/jas.v10i1.19094

URL: https://doi.org/10.5296/jas.v10i1.19094

\begin{abstract}
The growing demand for nutritious protein-rich foods has increased the visibility of the wild animal meat market, and created an alternative replacement for traditional meats. The informality in this product offer is a characteristic feature of this market. It is necessary to certify the existence of a public in this market niche. This segmentation of the wild animal meat consumer market in Belém municipality, Pará state, in the Brazilian Amazon, was carried out to identify consumers' perceptions of the economic potential of this activity. Data were obtained from a representative sample of consumers in Belém, one of the most representative consumption centers in the Amazon. Market segmentation was performed using two multivariate techniques: factor analysis to simplify the original data matrix, and cluster analysis to identify homogeneous groups according to the highest degree of similarity of objects in relation to the attributes of interest. The survey results showed that factors such as consumption preferences, product availability, education level, income, and family composition are determinants of the consumption of wild animal meat. The study also confirmed the existence of a market for this product in food establishments such as bars and restaurants. The main wild animal meats consumed were tartaruga-da-Amazônia (Podocnemis expansa) (61.67\%), alligator (Alligatoridae) (56.67\%), paca (Cuniculus paca) (52.50\%), deer (Cervidae) (40.83\%), armadillo (Dasypodidae) (40.00\%), muçuã (Kinosternon scorpioides) (30.83\%), capybara (Hydrochoerus hydrochaeris) (29.58\%), tortoise (Chelonoidis) (21.25\%), tracajá (Podocnemis unifilis) (19.58\%), peccary (Pecari tajacu) (17.08\%) and sloth (Folivora) (12.92\%). The expansion of this market, requires strategies to strengthen the regular sustainable supply of the product, including public initiative efforts regarding the regulatory framework of the activity and entrepreneurial efforts for the necessary investments in breeding and slaughtering system officers.
\end{abstract}

Keywords: amazon - sustainable livestock, cluster analysis, exotic meats, marketing

\title{
1. Introduction
}

In areas where indigenous populations live, hunting wild animals is still a very important practice from the point of view of food sovereignty, as many populations still maintain the traditional practice of consuming these meats (Reis and Queiroz, 2018). 
Although these discussions usually permeate under rural realities (Valsecchi and Amaral, 2009; Reis and Queiroz, 2018), the expansion of such consumption has been gaining strength due to the perception of the wild animal meat market as a potential source of interest to chefs, restaurant owners, and animal wild farmers (Oliveira et al., 2018).

In this context, many studies have been carried out to evaluate the production of wild animals as a sustainable use strategy (Nogueira and Nogueira-Filho, 2000; Souza et al., 2014; Amaral et al., 2016; Oliveira et al., 2018).

However, despite the growing interest in this area, the national market for exotic meats remains largely informal. Hence, it is important to carry out studies that demonstrate the potential for sustainable production and changing the perception of consumers regarding these types of meats.

One of the reasons that can boost the supply of wild animal meat is the expectation regarding the expansion of investments in sustainable breeding, as a way to consolidate the consumer market. Oliveira et al. (2018) highlight that this perspective is also important in promoting the diversification of production, increasing food security, creating a source of income for small farmers, and reducing negative interference in the environment by combating predatory and illegal hunting.

Regarding the economic aspects, Inovas et al. (2017) indicates a movement in the market (trade) due to the legal trade in Amazonian species (including wild animals) of around US\$128 million per year. The exploitation of wild animals has also increased because of the greater demand for protein-rich foods with lower caloric value and fat levels, and high nutritional values (Pereira et al., 2006). However, further studies are needed to confirm the existence of a consumer demographic in this market niche.

To fill this gap, market segmentation was carried out in this study to qualify the profile of wild animal meat consumers in the municipality of Belém in the state of Pará. This segmentation was done using variables such as age, sex, income, and education level, among others, which according to Kotler (2012), are usually associated with the needs and desires of consumers.

In this sense, this study aims to inform entrepreneurs and public policymakers about the potential of this market in the municipality of Belém and, by extrapolation, to other consumption centers in the Amazon. Further, subsidizing strategic guidelines and investments can consolidate the market that can emerge on a sustainable basis in the region, with good results for agribusiness entrepreneurs, including family-based ones, as well as for consumers, with a greater supply of healthy and legalized meat in both urban and rural areas.

\section{Market Segmentation: Theoretical Aspects}

The strategic positioning of a company is a crucial step in achieving the expected results within the market sphere. The positioning decisions that are essential for minimizing risks must be based on prior studies. One widely used tool to ensure consistency and effectiveness in decision-making is market segmentation (Folharini and Farias, 2012). 
As a strategic resource, its essence is to divide the market into well-defined slices, so that each slice is represented by a group of customers who share the same needs and desires. In this way, the company can direct its efforts to reach the target audience to satisfy their demands (Kotler, 2012).

An organization is responsible for managing its actions in the market. Tavares et al. (2011) highlight some practical utilities acquired by using this method: a) help in making decisions about the segments to focus on, b) identifying strategic possibilities to stimulate the offer of differentiated products, and c) highlighting the importance of business proactivity in coordination and administration activities.

Cluster analysis is among the most used multivariate techniques in conducting studies in the area of marketing and segmentation. The principle of the technique is based on a similarity measure to create homogeneous groups called clusters. Initially, all cases are presented individually, and as the process is conducted, groups are formed according to the greatest degree of similarity in the variables of interest. At the end of the process, each specific case is grouped into a cluster.

The basis for market segmentation is the use and analysis of variables that best explain the variation in the population being studied. In general, the variables used in this technique may be related to descriptive characteristics, such as geographic, demographic, and psychographic information, or associated with behavioral issues, such as consumer responses to certain benefits, usage occasions, and brands (Kotler, 2012).

A cluster analysis is conducted with the formulation of the problem to be studied and the definition of the variables that will serve as a basis for agglomeration. Then, we choose the distance measure that determines the degree of similarity or difference between the objects that will be clustered. With this in mind, the researcher should choose the agglomeration procedure that best suits the research problem and then decide on the most appropriate number of clusters. Hair Jr et al. (2009) and Malhotra (2012) provide a detailed review of this technique.

In some cases, factor analysis precedes the cluster methodology because of the gathering of variables that have a strong correlation with each other (Hair Jr et al., 2009). Therefore, the combination of these techniques is essential in studies involving market research, because the task of summarizing and managing consumer attitudes becomes simpler, taking into account the simplification of variables into factors.

Finally, the segmentation must result in the identification of the main characteristics of the target market, so that it provides the key elements to evaluate the company's possibilities to serve that market. Based on these elements, strategic actions must be conducted with respect to company and customer satisfaction (Tavares and Santos, 2006).

\section{Methodology}

\subsection{Study Area and Data Used in the Research}

The survey was conducted in Belém municipality, Pará state, which had 1,492,745 Instituto 


\section{Macrothink

Brasileiro de Geografia e Estatística (IBGE) inhabitants in 2020. It is the largest consumption center in Pará state and the second in the Brazilian Amazon. Therefore, it is highly representational in the regional context.

The data were collected through a semi-structured questionnaire distributed using random sampling to 395 individuals over 18 years of age in nine neighborhoods of the capital of Pará, representing a significant sample with a $95 \%$ confidence interval and a sampling error of $5 \%$. The neighborhoods were selected to represent, in the same proportion, three income strata, namely: i) high (Nazaré, Reduto, and Batista Campos neighborhoods), ii) average (Souza, Marco, and Pedreira neighborhoods), and iii) low (Jurunas, Guamá, and Reduto neighborhoods). Respondents, in turn, were approached on public streets in the commercial areas of these neighborhoods, close to supermarkets and fairs.

The data collection instrument questions were grouped into three blocks: i) socioeconomic conditions of respondents, ii) attributes of the demand for wild animal meat, and iii) demand for wild animal by-products (oils, lard, and leather).

\subsection{Developed Analysis}

Data were tabulated in Microsoft Excel and analyzed using the IBM Statistical Package for Social Sciences (SPSS) version 22.0 for Windows, using a Windows 7 operating system. Two procedures were performed: i) factor analysis to extract the most representative variables in the form of factors, and ii) cluster analysis to group consumers according to the highest degree of similarity concerning the variables of interest, as described below.

\subsubsection{Factor Analysis}

Factor analysis is a multivariate statistical method used to reduce and summarize data. It allows the analysis of the relationships between a set of correlated variables, simplifying them by defining a set of common latent dimensions, called factors (Hair Jr et al., 2009).

The basic factor analysis model can be specified

below: $X_{i}=A_{i 1} F_{1}+A_{i 2} F_{2}+A_{i 3} F_{3}+\ldots+A_{i k} F_{k}+U_{i}+E_{i}$

Where:

$X_{i}=$ are the variables that specify the characteristics of consumers;

$F_{k}=$ are the kth common factors;

$A_{i k}=$ are the factor loadings that indicate the intensity of the relationships between the variables and factors;

$U_{i}=$ is the single factor that specifies the part of the total variance that is not associated with the 
variance of the other variables;

$E_{i}=$ is the error factor representing the model's observation, measurement or specification error.

Factor analysis assumes that there is a correlation between the analyzed variables. The quality of these correlations was assessed using the Bartlett and Kaiser-Meyer-Olkin (KMO) sphericity tests. The first tests the null hypothesis that the correlation matrix is an identity matrix whose determinant is equal to one. The second, whose value varies between zero and one, compares the zero-order correlations with the partial correlations observed between the variables (Hair Jr et al., 2009). The execution of these tests is necessary, as it indicates whether the data are suitable for the application of factor analysis.

Using IBM SPSS 22.0, the factors were estimated using the principal components method, and those that presented characteristic roots greater than the unit were selected. From the extracted factors, the factor scores were estimated using a method similar to that used for the regression. The general expression for estimating the $\mathrm{jth}$ factorial score $(\mathrm{Fj})$ is given by: $F_{j}=W_{i 1} X_{1}+W_{i 2} X_{2}+W_{i 3} X_{3}+\ldots+W_{i p} X_{p}$

where $W_{j i}$ are the coefficients of the factor scores, and $\mathrm{p}$ is the number of variables.

\subsubsection{Cluster Analysis}

After obtaining the factors, a cluster analysis was applied to group the number of observations in a data matrix. That is, we simultaneously consider both-the number of variables linked to the factors, and the number of observations. The cluster analysis, consists of the formation and identification of homogeneous groups, which are divided according to the degree of proximity between them.

The measurement of the degree of proximity between objects was conducted using Ward's method, which is an agglomerative hierarchical method that measures the similarity between observations through the square of the Euclidean distance (Malhotra, 2012).

In this study, based on the factor scores, cluster analysis was used to segment consumers and form homogeneous groups. The best solution obtained was four groups (clusters).

\subsection{Definition of Variables}

Twelve variables were used to reflect the main characteristics of the interviewed consumers and their respective perceptions of wild animal meat consumption (X1 to X12), as specified in Table 1. 
Table 1. Definition of the variables used in the factor analysis

\begin{tabular}{cl}
\hline Indicators & \multicolumn{1}{c}{ Specification } \\
\hline $\mathrm{X}_{1}$ & Types of wild animal meats you've already eaten \\
\hline $\mathrm{X}_{2}$ & Wild animal meat cooking preferences \\
\hline $\mathrm{X}_{3}$ & Wild animal meat preparation preferences \\
\hline $\mathrm{X}_{4}$ & Wild animal meat cuts preferences \\
\hline $\mathrm{X}_{5}$ & Would you consume wild animal meat if it was being sold at an open market? \\
\hline $\mathrm{X}_{6}$ & Would you buy wild animal meat if it was being sold in a supermarket? \\
\hline $\mathrm{X}_{7}$ & Would you eat wild animal meat in a restaurant? \\
\hline $\mathrm{X}_{8}$ & Education degree \\
\hline $\mathrm{X}_{9}$ & Income \\
\hline $\mathrm{X}_{10}$ & Gender \\
\hline $\mathrm{X}_{11}$ & Age \\
\hline $\mathrm{X}_{12}$ & Family Size - How many people live in your household? \\
\hline
\end{tabular}

Source: Research data.

\section{Results and Discussion}

\subsection{Determining Factors of Wild Animal Meat Consumption}

The application of factor analysis provided the extraction of four factors with characteristic roots greater than the unit, which summarizes the information contained in the 12 original variables. These factors explain $68.06 \%$ of the total variance in the model (Table 2).

Bartlett's test was significant at levels below $1 \%$ probability, rejecting the null hypothesis that the correlation matrix is an identity matrix. The KMO test showed a value of 0.7784 , indicating that the method is suitable for data analysis (Table 2).

Table 2 shows the factor loadings and commonalities of the four factors considered. The values obtained for the commonality reveal that practically all the variables have significant variability, captured and represented by the four factors.

Table 2. Factor loadings after orthogonal rotation and the respective commonalities

\begin{tabular}{|c|c|c|c|c|c|}
\hline \multirow[t]{2}{*}{ Variable } & \multicolumn{4}{|c|}{ Factors } & \multirow{2}{*}{$\begin{array}{l}\text { Commona } \\
\text { lities }(*)\end{array}$} \\
\hline & F1 & $\mathrm{F} 2$ & F3 & F4 & \\
\hline Types of wild animal meats you've already eaten & 0.7508 & 0.2444 & -0.0311 & -0.2193 & 0.6725 \\
\hline Wild animal meat cooking preferences & 0.8689 & 0.2308 & 0.0374 & -0.0983 & 0.8193 \\
\hline Wild animal meat preparation preferences & 0.9075 & 0.0573 & 0.0109 & -0.0706 & 0.8319 \\
\hline Wild animal meat cuts preferences & 0.8762 & 0.1919 & 0.0390 & -0.0323 & 0.8072 \\
\hline Would you consume wild animal meat if it was being sold at an open market? & 0.1606 & 0.7502 & -0.2033 & 0.0459 & 0.6319 \\
\hline Would you buy wild animal meat if it was being sold in a supermarket? & 0.1727 & 0.8613 & 0.0496 & -0.0334 & 0.7752 \\
\hline Would you eat wild animal meat in a restaurant? & 0.1978 & 0.8306 & 0.0558 & -0.1150 & 0.7454 \\
\hline Education degree & -0.0475 & -0.1312 & 0.8468 & 0.1425 & 0.7568 \\
\hline Income & 0.0631 & 0.0371 & 0.8599 & -0.1342 & 0.7627 \\
\hline Gender & -0.2200 & -0.2208 & -0.2617 & 0.4326 & 0.3528 \\
\hline
\end{tabular}




\begin{tabular}{lrrrrrr}
\hline Age & 0.2624 & -0.0492 & -0.1011 & -0.5533 & 0.3876 \\
\hline Family Size & 0.0745 & -0.0222 & -0.0033 & 0.7854 & 0.6230 \\
\hline Explained Variance (\%) & 26.12 & 18.48 & 13.22 & 10.24 & - \\
\hline Accumulated Explained Variance (\%) & 26.12 & 44.60 & 57.82 & 68.06 & - \\
\hline
\end{tabular}

Source: Research data.

Note: (*) Proportion of the total variance of the explained variable by common factors. The factors with the greatest weight per variable are indicated in bold.

Bartlett's sphericity test $=1,840.42(\mathrm{p}<0.01)$ and $\mathrm{KMO}=0.7784$.

F1, consumption preference; F2, product availability; F3, level of education and income; F4, family composition

From the analysis of Table 2, Factor 1 represents the largest portion of variance among the four factors obtained $(26.12 \%)$ and is positively and strongly associated with variables linked to consumer satisfaction regarding the attributes of wild animal meat, such as the type of meat, cooking, preparation, and cutting. Factor 1, therefore, was defined as "Consumption preference."

Factor 2 is positively and strongly related to variables related to meat origin (fairs, supermarkets, or restaurants). Factor 2 was defined as "Product availability" and explained $18.48 \%$ of the total data variation.

Factor 3 is positively and strongly related to variables associated with consumer education and income, called "Level of education and income." This factor explained $13.22 \%$ of the total data variation.

Factor 4 explained $10.24 \%$ of the total variation in the data and is positively associated with gender, age, and family size. These variables are demographic characteristics linked to consumers that drive different behaviors in the daily lives of families. This factor was called "Family composition."

\subsection{Cluster Analysis}

The market segmentation for wild animal meat using cluster analysis allowed the extraction of relevant information about the socioeconomic aspects and consumption habits of the interviewees for each identified group. Thus, analyses of each topic in the questionnaire, shown below, are segmented by a consumer group.

\subsubsection{Sociodemographic Characteristics}

The socioeconomic and demographic characteristics of the respondents are presented in Table 3. Among the 395 participants, $60.76 \%$ responded positively to the consumption of wild animal meat. A total of $39.24 \%$ of participants indicated that they did not eat these foods. 
Table 3. Sociodemographic and economic characteristics of respondents $(n=395)$ in Belém municipality, Pará state by cluster $(\%)$

\begin{tabular}{|c|c|c|c|c|c|c|}
\hline \multirow[t]{2}{*}{ Characteristic } & \multirow[t]{2}{*}{ Profile } & \multicolumn{3}{|c|}{ Clusters } & \multicolumn{2}{|r|}{ Total } \\
\hline & & $\mathrm{I}(\mathrm{n}=134)$ & II $(n=79)$ & III $(n=69)$ & IV $(n=113)$ & $\mathrm{n}=395$ \\
\hline Have you ever consumed & Not & 14.18 & 68.35 & 86.96 & 19.47 & 39.24 \\
\hline wild animal meat? & Yes & 85.82 & 31.65 & 13.04 & 80.53 & 60.76 \\
\hline \multirow[t]{3}{*}{ Gender } & Man & 26.87 & 46.84 & 5.80 & 45.13 & 32.41 \\
\hline & Woman & 73.13 & 53.16 & 94.20 & 54.87 & 67.59 \\
\hline & Less than 30 years old & 10.45 & 20.25 & 33.33 & 15.04 & 17.72 \\
\hline \multirow[t]{5}{*}{ Age group } & From 30 to 40 years old & 19.40 & 29.11 & 31.88 & 15.04 & 22.28 \\
\hline & From 41 to 50 years old & 19.40 & 17.72 & 23.19 & 23.89 & 21.01 \\
\hline & From 51 to 60 years old & 23.88 & 16.46 & 8.70 & 21.24 & 18.99 \\
\hline & Over 60 years old & 26.87 & 16.46 & 2.90 & 24.78 & 20.00 \\
\hline & Single & 21.97 & 32.05 & 57.97 & 35.40 & 34.18 \\
\hline \multirow[t]{6}{*}{ Marital status } & Married & 31.06 & 50.00 & 26.09 & 27.43 & 32.91 \\
\hline & Widower & 15.15 & 2.56 & 1.45 & 15.04 & 10.20 \\
\hline & Stable union & 22.73 & 10.26 & 11.59 & 13.27 & 15.56 \\
\hline & Divorced & 9.09 & 5.13 & 2.90 & 8.85 & 7.14 \\
\hline & Illiterate & 0.00 & 0.00 & 0.00 & 3.54 & 1.01 \\
\hline & Incomplete Elementary school & 19.40 & 0.00 & 5.80 & 19.47 & 13.16 \\
\hline Instruction & Elementary school & 14.93 & 0.00 & 8.70 & 11.50 & 9.87 \\
\hline \multirow[t]{8}{*}{ Level } & Incomplete high school & 12.69 & 0.00 & 15.94 & 22.12 & 13.42 \\
\hline & High school & 36.57 & 25.32 & 60.87 & 33.63 & 37.72 \\
\hline & Incomplete undergraduate & 5.22 & 12.66 & 4.35 & 2.65 & 5.82 \\
\hline & Undergraduate & 11.19 & 59.49 & 4.35 & 7.08 & 18.48 \\
\hline & Graduate & 0.00 & 2.53 & 0.00 & 0.00 & 0.52 \\
\hline & Below or equal to one MW & 26.87 & 2.53 & 42.03 & 26.55 & 24.56 \\
\hline & Above 1 to $2 \mathrm{MW}$ & 37.31 & 8.86 & 49.28 & 46.02 & 36.20 \\
\hline & Above 2 to $3 \mathrm{MW}$ & 19.40 & 15.19 & 4.35 & 12.39 & 13.92 \\
\hline \multirow[t]{6}{*}{ Income range } & Above 3 to $4 \mathrm{MW}$ & 9.70 & 15.19 & 4.35 & 7.96 & 9.37 \\
\hline & Above 4 to $5 \mathrm{MW}$ & 0.75 & 12.66 & 0.00 & 6.19 & 4.56 \\
\hline & Above 5 to $6 \mathrm{MW}$ & 3.73 & 15.19 & 0.00 & 0.88 & 4.56 \\
\hline & Above 6 to $8 \mathrm{MW}$ & 1.49 & 12.66 & 0.00 & 0.00 & 3.04 \\
\hline & Above 8 to $10 \mathrm{MW}$ & 0.75 & 11.39 & 0.00 & 0.00 & 2.53 \\
\hline & Above $10 \mathrm{MW}$ & 0.00 & 6.33 & 0.00 & 0.00 & 1.27 \\
\hline
\end{tabular}

Source: Research data. Note: MW: Minimum Wage

The cluster analysis presents very interesting results. Cluster I, for example, is mostly composed of women (73.13\%), those aged over 51 years $(50.75 \%)$, married $(31.06 \%)$, who have completed secondary education $(36.57 \%)$, and are wild animal meat consumers (85.82\%). The income range is another highlight, as $83.58 \%$ of these families survive on an income of up to three minimum wages. Therefore, considering these factors, the first cluster was called "Mature, consumer, and low-income women."

The second group is composed of young people, aged up to 40 years old (49.37\%), married $(50.00 \%)$, with a high level of education, as in this group, $62.02 \%$ of individuals have completed undergraduate and graduate education, and income ranging between more than five minimum wages and more than ten salaries, accounting for $45.57 \%$ of respondents. It should be noted that this was the top-most cluster, in terms of income. In addition, this group is characterized by a majority $(68.35 \%)$ who are not fond of wild animal meat. Thus cluster II 
was named "Young people, non-consumers, and middle-high income people."

Similar to cluster I, women were the vast majority in the third group (94.20\%). Regarding the consumption of wild animal meat, $86.96 \%$ responded negatively. The age group was concentrated in young people, aged up to 40 years old $(65.22 \%)$, single (57.97\%), educated up to high school (60.87\%), and with income up to two minimum wages (91.30\%). For these reasons, cluster III was designated "Young, non-consuming, and low-income women."

In the fourth group comprising $28.61 \%$ of the sample, $45.13 \%$ were males and $54.87 \%$ females. Among this group, $80.53 \%$ reported having already consumed wild animal meat. Regarding the profile of these individuals, participants aged over 41 years (69.91\%), single $(35.40 \%)$, with a level of education up to complete high school (86.73\%), and income higher than One to three minimum wages $(84.96 \%)$. Given this, cluster IV was called "Mature, consumer, and low-income people."

Considering that the study was conducted in Belém city, the number of participants who responded that they had never consumed wild animal meat can be explained by the low availability of these products on the market, lack of knowledge of the nutritional properties of meat, or even fear of consumption of proteins that are little known in the region. Contrary to the profile of the urban population, riverside communities demonstrate greater control over these practices, which results in a greater supply and regular consumption of these products in the interior regions of the state (Brito et al., 2016). Even in urban areas of municipalities in the interior of Pará, such as Abaetetuba, it is common to identify a large prevalence of wild animal meat from illegal hunting in their traditional open markets.

However, negative responses do not negate the possibility that these individuals will be considered potential consumers. This is because the justification for these answers may involve questions related to the lack of an opportunity to taste this product. In other words, the fact that the respondents have never consumed wild animal meat does not necessarily mean that they have any reservations regarding this consumption.

\subsubsection{Access to Information}

Regarding the aspects related to access to information, Table 4 shows that the respondents grouped in clusters I and IV pointed out Television (TV news) as their main source of news, where the participation for each cluster was $76 \%, 87 \%$, and $79.65 \%$, respectively. This result reinforces the idea that mature people are more likely to have TV news as a basic informational vehicle. The ease of access to this resource indicates that television is still considered an important disseminator of information, especially when it comes to older, low-income people, whose access to information is limited.

Clusters II and III exhibited a more varied behavior, with emphasis on a majority who are informed through newscasts and/or Internet access, accounting for $83.55 \%$ and $97.1 \%$ of respondents, respectively. Therefore, it is understood that the age range of these groups influenced the results, as they are composed of a majority of young people and are possibly more used to getting information from the Internet, compared to mature people listed in the other groups. The level of education is another feature that influences Internet usage. In 
general, the prospect of using the Internet tends to grow with an increase in the level of education (IBGE, 2016).

Table 4. Main sources of information/access to news of respondents $(n=395)$ in the Belém municipality, Pará state by cluster (\%).

\begin{tabular}{llllll}
\hline Source & \multicolumn{3}{c}{ Clusters } & Total \\
\cline { 2 - 6 } & $\mathrm{I}(\mathrm{n}=134)$ & $\mathrm{II}(\mathrm{n}=79)$ & $\mathrm{III}(\mathrm{n}=69)$ & $\mathrm{IV}(\mathrm{n}=113)$ & $\mathrm{n}=395$ \\
\hline Newspaper & 8.96 & 13.92 & 1.45 & 9.73 & 8.86 \\
\hline Television (TV news) & 76.87 & 46.84 & 82.61 & 79.65 & 72.66 \\
\hline Internet/Social networks & 8.21 & 36.71 & 14.49 & 7.96 & 14.94 \\
\hline Radio & 5.97 & 2.53 & 1.45 & 2.65 & 3.54 \\
\hline
\end{tabular}

Source: Research data.

Previous research has shown that several factors influence the perpetuation of hunting activities and animal consumption, including sex, income, and educational level (Fuccio et al., 2003; Alves et al., 2012; Pezzuti et al., 2018). In the present study, clusters II and III comprise together younger people with a greater degree of access to information, higher education, and variable income between low, medium, and high. In this context, the lower predisposition to the consumption of wild animal meat by these groups appears to reaffirm the influence of socioeconomic factors on these practices, considering that the largest number of individuals who have never consumed this product were associated with clusters II (68, $35 \%)$ and III (86.96\%), whose respondents appear to enjoy better income conditions (cluster II) and education (II and III), and therefore, do not need to resort to this meat market, which may also be associated with consumption of a low-quality product.

\subsubsection{Most Consumed Meats}

In all, 21 species of animals consumed by the respondents were identified, as shown in Table 5. During the survey, there were considerable similarities in the responses, possibly due to factors related to greater availability of the species in the region, degree of difficulty and cost of meat, flavor and meat yield, or influence of purchase and resale prices of this product (Brito, et al. 2016; Damaceno et al., 2019). The most appreciated meats came from the following animals: tartaruga-da-Amazônia (Podocnemis expansa) (61.67\%), alligator (Alligatoridae) (56.67\%), paca (Cuniculus paca) (52.50\%), deer (Cervidae) (40.83\%), armadillo (Dasypodidae) (40.00\%), muçuã (Kinosternon scorpioides) (30.83\%), capybara (Hydrochoerus hydrochaeris) (29.58\%), tortoise (Chelonoidis) (21.25\%), tracajá (Podocnemis unifilis) (19.58\%), peccary (Pecari tajacu) (17.08\%), and sloth (Folivora) $(12.92 \%)$. 
Table 5. Meat most consumed by respondents $(n=240)$ in Belém municipality, Pará state, by species and cluster $(\%)$

\begin{tabular}{|c|c|c|c|c|c|}
\hline \multirow[t]{2}{*}{ Species } & \multicolumn{4}{|l|}{ Clusters } & \multirow[b]{2}{*}{ Total $\left(\mathrm{n}=240^{*}\right)$} \\
\hline & $\mathrm{I}(\mathrm{n}=115)$ & II $(\mathrm{n}=25)$ & III $(n=9)$ & IV $(n=91)$ & \\
\hline Tartaruga-da-Amazônia (P. expansa) & 53.04 & 76.00 & 44.44 & 70.33 & 61.67 \\
\hline Alligator (Alligatoridae) & 53.04 & 52.00 & 66.67 & 61.54 & 56.67 \\
\hline Paca (Cuniculus paca) & 47.83 & 48.00 & 44.44 & 60.44 & 52.50 \\
\hline Deer (Cervidae) & 39.13 & 28.00 & 22.22 & 48.35 & 40.83 \\
\hline Armadillo (Dasypodidae) & 37.39 & 32.00 & 22.22 & 47.25 & 40.00 \\
\hline Muçuã (K. scorpioides) & 25.22 & 32.00 & 11.11 & 39.56 & 30.83 \\
\hline Capybara (H. hydrochaeris) & 25.22 & 16.00 & 11.11 & 40.66 & 29.58 \\
\hline Tortoise (Chelonoidis) & 23.48 & 12.00 & 11.11 & 21.98 & 21.25 \\
\hline Tracaja (P. unifilis) & 15.65 & 24.00 & 11.11 & 24.18 & 19.58 \\
\hline Peccary (P. tajacu) & 14.78 & 8.00 & 11.11 & 23.08 & 17.08 \\
\hline Sloth (Folivora) & 13.04 & 0.00 & 0.00 & 17.58 & 12.92 \\
\hline Agouti (Dasyprocta) & 7.83 & 4.00 & 0.00 & 12.09 & 8.75 \\
\hline Tapirus (Tapirus terrestris) & 4.35 & 4.00 & 0.00 & 10.99 & 6.67 \\
\hline Chameleon (Chamaeleonidae) & 5.22 & 8.00 & 0.00 & 4.40 & 5.00 \\
\hline Mucura (Didelphis marsupialis) & 3.48 & 0.00 & 11.11 & 6.59 & 4.58 \\
\hline Snake (Serpentes) & 1.74 & 8.00 & 0.00 & 5.49 & 3.75 \\
\hline Monkey (Primates) & 2.61 & 0.00 & 0.00 & 5.49 & 3.33 \\
\hline Maned (Chrysocyon brachyurus) & 0.87 & 4.00 & 0.00 & 0.00 & 0.83 \\
\hline Coati (Nasua) & 0.00 & 0.00 & 0.00 & 1.10 & 0.42 \\
\hline Jacuraru (Tupinambis teguixin) & 0.00 & 0.00 & 0.00 & 1.10 & 0.42 \\
\hline Anteater (Myrmecophaga tridactyla) & 0.00 & 0.00 & 0.00 & 1.10 & 0.42 \\
\hline
\end{tabular}

Source: Research data.

Note: Respondents could provide more than one answer option.

* Corresponding to the total number of individuals who stated they consume wild animal meat.

The higher level of consumption of turtles (Tartaruga-da-Amazônia, muçuã, tortoises e tracajá) is related to access to these animals, given that the Brazilian Amazon stands out for a greater prevalence of these species (Ibama, 2016), which resulted in the development of an important consumption habit in the areas that these animals are found. For this reason, animal capture is recurrent, and breeding occurs easily in residential backyards and farms.

The interest in alligator hunting is mainly due to the leather trade that achieves very compensatory values in the international market (Souza et al., 2014). Following the slaughter line, the use of alligator meat occurs in a complementary way, serving as an option for a protein source, especially in riverside communities that suffer from a lack of alternatives for food and income (Chagas and Bernhard, 2017).

The paca also proved to be highly appreciated. This is possibly due to the taste of the meat, 
which confers a good reception to consumers (Cajaiba et al., 2015; Damasceno et al., 2019).

Deer is characteristic of several habitats, as dense forests with few patches of forest are suitable places for their refuge or feeding. Other factors that make deer susceptible to hunting and, consequently, to consumption, are their daytime habits and the ease of approaching these animals (Duarte et al., 2012).

As it is considered a general species, since there are few restrictions on its feeding, the armadillo can also be found easily in different habitats, such as in areas of open vegetation or secondary forest. Deforestation is now a common occurrence in the Amazon region (Cajaiba et al., 2015; Damasceno et al., 2019). Therefore, the wide availability of these animals is a determining factor for greater predation.

\subsubsection{Meat Origin}

Regarding the meat origin, all classifications by clusters showed results that converged to consumption from hunting $(82.50 \%)$, followed by acquisition in open markets $(9.17 \%)$, unknown origin $(9.17 \%)$, restaurants $(5.0 \%)$, and finally, direct procurement from supermarkets $(0.42 \%)$, as shown in Table 6.

Table 6 . Origin of meat consumed by respondents, by cluster (\%).

\begin{tabular}{|c|c|c|c|c|c|}
\hline \multirow[t]{2}{*}{ Origin } & \multicolumn{4}{|c|}{ Clusters } & \multirow[b]{2}{*}{ Total $(n=240 *)$} \\
\hline & $\mathrm{I}(\mathrm{n}=115)$ & II $(n=25)$ & III $(n=9)$ & IV $(n=91)$ & \\
\hline Hunting & 78.26 & 80.00 & 77.78 & 89.01 & 82.50 \\
\hline Open fair & 9.57 & 4.00 & 33.33 & 7.69 & 9.17 \\
\hline Supermarkets & 0.87 & 0.00 & 0.00 & 0.00 & 0.42 \\
\hline Restaurants & 2.61 & 20.00 & 0.00 & 4.40 & 5.00 \\
\hline Origin unknown/unreported & 15.65 & 4.00 & 0.00 & 3.30 & 9.17 \\
\hline
\end{tabular}

Source: Research data.

Note: Respondents could provide more than one answer option.

* Corresponding to the total number of individuals who consumed wild animal meat.

Through this information, it becomes evident that a considerable number of respondents indicate consumption habits from hunting, which implies a situation of illegal exploitation of available resources in the environment, causing predation on natural populations (Nogueira and Nogueira-Filho, 2008; Cajaiba et al., 2015; Brito et al., 2016).

The use of wild animals is not restricted to food practices, as they are also used as ingredients in medicines, for breeding, or as exotic pets. Therefore, it is necessary to be very careful about the unscrupulous classification of individuals involved in these activities as criminal animal traffickers, given that extending these labels to certain social groups means ignoring cultural aspects that are fundamental to the development and survival of people from rural communities (Ruas et al., 2017).

The wild animal meat market continues in rural and urban areas of the Amazon, even though 
it is seen as illegal and "invisible" by many institutional profiles. Therefore, further debate is needed about the importance of these practices for food sovereignty and regional development, reinforcing issues that allow guiding policies for the sustainable use of these resources based on the legal management of wild fauna (Van Vliet et al., 2014). From this perspective, production in rational systems can be seen as an alternative to income, food security, and sustainable business opportunities in rural areas, including the inclusion of small producers (Oliveira et al., 2018).

However, if the market is seen as illegal and invisible, why do these consumption habits persist in both rural and urban areas? Authors, such as Ruas et al. (2017), and Pezzuti et al. (2018), suggest that the main motivation would be related to the strong cultural value embedded in these practices. This is because the use of wild fauna presents a field of activity full of meanings that encourages many residents, including those in urban areas, to preserve culture and the pleasure of forest cuisine.

This situation, as mentioned above, reinforces the need to implement and improve public policies related to wildlife management. Therefore, government actions could adopt as a strategy to encourage the creation of wild animals in captivity, based on research (Pereira et al., 2006; Nogueira and Nogueira-Filho, 2008; Souza et al., 2012; Oliveira et al., 2018) that demonstrate that investment in this product segment is viable.

This initiative would have a great impact on the legal use of fauna at the regional level, given that these activities facilitate the process of obtaining animal protein, serve as a source of income for those involved, and also collaborate to strengthen the local market through the regular offer (Damaceno et al., 2019). In the sustainable field, the direct gains from the adoption of these practices can be seen mainly through the preservation of the natural population of wild species.

\subsubsection{Consumption Places}

Table 7 analyzes the main places of consumption indicated by the respondents. Through these interpretations, it is clear that the participation of cities in the interior of the state is high (70.83\%), since most research participants claimed that this is the most common place to consume such foods. Thus, these observations suggest that consumption in the Belém Metropolitan Region (BMR) is more common.

Table 7. Main consumption places of respondents, by cluster (\%)

\begin{tabular}{llllll}
\hline \multirow{2}{*}{ Consumption place } & \multicolumn{2}{l}{ Clusters } & & & \\
\cline { 2 - 5 } Total $(\mathrm{n}=240 *)$ \\
\cline { 2 - 5 } In cities in the interior of Pará state (on trips) & 64.35 & 68.00 & 66.67 & 80.22 & 70.83 \\
\hline Residence & 26.09 & 36.00 & 44.44 & 23.08 & 26.67 \\
\hline Restaurants and bars & 0.87 & 8.00 & 0.00 & 3.30 & 2.50 \\
\hline Home of friends and family in Belém & 7.83 & 12.00 & 0.00 & 1.10 & 5.42 \\
\hline Another state & 3.48 & 8.00 & 0.00 & 4.40 & 4.17 \\
\hline other places & 4.35 & 0.00 & 0.00 & 2.20 & 2.92 \\
\hline
\end{tabular}


Source: Research data.

Note: Respondents could provide more than one answer option.

* Corresponding to the total number of individuals who consumed wild animal meat.

Other common responses were related to consumption at home $(26.67 \%)$, at the homes of friends and family in Belém (5.42\%), or even in restaurants and bars $(2.50 \%)$. This information proves the informality of this market, as few people buy and consume these products in places assisted by surveillance and sanitary inspection bodies.

The strong participation of family and friends in sharing and reselling these products reveals that this activity sometimes represents the consolidation of bonds between relatives and close people (Van Vliet et al., 2014).

The general results indicate the existence of an acceptance potential for exotic meats in bars and restaurants in the city. Nogueira and Nogueira-Filho (2008) support these discussions and emphasize that, from the perspective of gastronomy, these products represent an important differential for food establishments, as they attract customers, especially tourists, interested in consuming exotic cultural foods. Likewise, this was noticed in the case of peccary in the branch of steakhouses in Belém city in the research developed by Oliveira et al. (2018).

\section{Final Considerations}

The most influential factors in the consumption of wild animal meat were related to consumer preferences, product availability, level of education, income, and family composition.

The segmentation results clearly show that there is a market for this product in the city of Belém. However, there is still a need to regularize the offer due to the direct interference it exerts on consumption and price variations. Therefore, it would be interesting to develop and implement public policies to encourage the production of meat from animals in captivity, with the aim of correcting the problems of irregular supply and pressure on environmental resources through the economic use of species.

The consumer public is represented by mature people (aged over 40 years), especially women and low-income individuals. Therefore, to compete more effectively, those interested in this activity should focus their marketing efforts on people who fit this profile.

Although the preferred place for wild animal meat consumption is associated with cities in the interior of the state, when interviewees moved to these places, the survey showed that there is a potential for acceptance of exotic meats in Belém and large cities. In this regard, it would be interesting to define strategies for a greater offer of the product based on the sustainable production of these animals.

\section{References}

Alves, R. R. N., Gonçalves, M. B. R., \& Vieira, W. L. S. (2012). Caça, uso e conservação de vertebrados no semiárido Brasileiro. Tropical Conservation Science, 5(3), 394-416. https://doi.org/10.1177/194008291200500312 
Amaral, A. G., Campos, J. C. D., Ramos, T. V., Taveira, R. Z., Silveira Neto, O. J., Gomes, R. C. C., \& Oliveira, O. A. M. (2016). Avaliação de mercado de carnes de animais silvestres e exóticos na região metropolitana de Goiânia. Espacios.

https://www.revistaespacios.com/a16v37n14/16371417.html. Link, 37(14) p. 17.

Brito, T. P., Lima, E. B. S., \& Rosa, J. C. G. S. (2016). Avaliação do consumo de quelônios no município de Castanhal-Pará-Brasil. Ouricuri. https://www.revistas.uneb.br/index.php/ouricuri/article/view/1367. Link, 6(1).

Cajaiba, R. L., Silva, W. B., \& Piovesan, P. R. R. (2015). Animais silvestres utilizados como recurso alimentar em assentamentos rurais no município de Uruará, Pará, Brasil. Desenvolvimento e Meio Ambiente, 34, 157-168. https://doi.org/10.5380/dma.v34i0.38889

Chagas, D. C., \& Bernhard, R. (2017). Aspectos da Caça e Comércio de jacaré [Crocodylia: Alligatoride]. no rio Copeá, no Município de Maraã (AM). http://177.66.14.82/bitstream/riuea/599/1/Aspectos\%20da\%20Ca\%c3\%a7a\%20e\%20Com\%c $3 \%$ a9rio $\% 20 \mathrm{de} \% 20$ jacar\%c3\%a9\%20\%28Crocodylia\%20Alligatoride $\% 29 \% 20$ no $\% 20$ rio $\%$ 20Cope \%c3\%a1\%2c\%20no\%20Munic\%c3\%adpio\%20de\%20Mara\%c3\%a3\%20\%28Am\%2 9.pdf. Amazonas, Brazil: Trabalho de Conclusão de Curso, Universidade do Estado do Amazonas.

Damaceno, A. B., Ortega, G. P., \& Turci, L. C. B. (2019). Uso da caça de subsistência no assentamento Santa Luzia, Cruzeiro do Sul, Acre. PUBVET, 13(2), 1-8. https://doi.org/10.31533/pubvet.v13n2a262.1-8

Duarte, J. M. B., \& Vogliotti, A. Zanetti, dos Santos. E., Oliveira. (2012) M. L. Tiepolo, L.M., Rodrigues, L. F., Almeida. L.B., Braga, F. G. Avaliação do risco de extinção do veado-campeiro Ozotoceros bezoarticus Linnaeus, 1758, no Brasil. Biodiversidade Brasileira, 1, 20-32. https://www.icmbio.gov.br/revistaeletronica/index.php/BioBR/article/view/235/152

Folharini, J. R., \& Farias, R. N. (2012). Segmentação de mercado aplicada ao posicionamento estratégico. Revista Anagrama. https://pdfs.semanticscholar.org/d786/6080250af5d0ff8582008c6e3d0395273fc7.pdf, 5(4).

Fuccio, H., Carvalho, E. F., \& Vargas, G. (2003). Perfil da caça e dos caçadores no Estado do Acre, Brasil. Aportes Andinos. http://www.insumisos.com/httpdocs/articulos/Perfil\%20da\%20ca\%E7a\%20e\%20dos\%20ca\% E7adores\%20no\%20Estado\%20do\%20Acre.pdf. Link, 6 (pp. 1-18).

Hair, J. R., J. F., Black, W. C., Babin, B. J., Anderson, R. E., \& Tatham, R. L. (2009). Análise multivariada de dados, $\sigma^{\mathrm{a}}$ ed. p. 688. Porto Alegre: Bookman.

IBAMA, \& Instituto Brasileiro do Meio Ambiente E dos Recursos Naturais Renováveis. (2016). Manejo conservacionista e monitoramento populacional de quelônios amazônicos. http://www.icmbio.gov.br/ran/images/stories/Downloads/Manual_Tecnico_Manejo_Monitora mento_Quelonios_Amazonicos_2016.pdf. Brasília. Link.

IBGE, Instituto Brasileiro de Geografia e Estatística. (2016). Pesquisa Nacional por Amostra 
de Domicílios Contínua: Acesso à internet e à televisão e posse de telefone móvel celular para uso pessoal 2016. https://biblioteca.ibge.gov.br/visualizacao/livros/liv101543.pdf. Brasil. Link.

IBGE, Instituto Brasileiro de Geografia e Estatística. Cidades IBGE. https://cidades.ibge.gov.br/. Retrieved March 072020

Kotler, P. Administração de marketing. [São Paulo: Pearson Education do Brasil]. (2012). p. 796.

Malhotra, N. (2012). Pesquisa de marketing uma orientação aplicada p. 798. Porto Alegre: Bookman.

Nogueira, S. S. C., \& Nogueira-Filho, S. L. G. (2008). Criação de animais silvestres em cativeiro: Uma alternativa à crescente pressão de caça e ao desmatamento nas florestas tropicais. In F. P. C. Silva, D. A. P. Gomes-Silva \& V. M. L. Nascimento (Eds.) (Org.). https://www.researchgate.net/publication/286458507_Criacao_de_Animais_Silvestres_em_C ativeiro_uma_alternativa_a_crescente_pressao_de_caca_e_ao_desmatamento_nas_florestas_t ropicais, Coletânea de textos: Manejo e Monitoramento de fauna Silvestre em Florestas Tropicais (first edn.). Rio Branco, 1 (pp. 236-248). Link.

Oliveira, B. P. D., Rebello, F. K., Albuquerque, N. I., Santos, M. A. S., \& Lopes, M. L. B. (2018). Análise da viabilidade econômico-financeira da criação comercial de caititus (Pecari tajacu) em áreas da Amazônia brasileira. Custos e Agronegócio Online. http://repositorio.ufra.edu.br/jspui/handle/123456789/658. Link, 14(4) (pp. 420-443).

Pereira, A. V., Romanelli, P. F., Scriboni, A. B., \& Orlandini, F. P. (2006). Rendimento do abate e composição da carne de Ema (Rhea americana). Ciência e Tecnologia de Alimentos, 26(3), 632-638. https://doi.org/10.1590/S0101-20612006000300023

Pezzuti, J. C. B., Antunes, A. P., Fonseca, R., Vieira, M. A. R., Valsecchi, J., Ramos, R. M., ... \& Ranzi, T. J. D. (2018). A caça e o caçador: Uma análise crítica da legislação brasileira sobre o uso da fauna por populações indígenas e tradicionais na Amazônia. Biodiversidade Brasileira.https://www.icmbio.gov.br/revistaeletronica/index.php/BioBR/article/view/779.Lin k, 8(2) (pp. 42-74).

Reis, Y. S., Valsecchi, J., \& Queiroz, H. (2018). Caracterização do uso da fauna silvestre para subsistência em uma unidade de conservação no Oeste do Pará. Biodiversidade Brasileira. V. http://www.icmbio.gov.br/revistaeletronica/index.php/BioBR/article/view/796/615, 8(2) (pp. 187-202).

Ruas, R. M. S., Furtado, D. C., Guerra, G. A. D., Lopes, C. TdA., \& Domingues, S. F. S. (2017). Caça, captura e uso da fauna silvestre no brasil como crimes ambientais e tabu científico: Reflexão sobre categorias teóricas. Holos, 5.

https://doi.org/10.15628/holos.2017.5660

Sinovas, P., Price, B., King, B. P. E., Hinsley, A., \& Pavitt, A. (2017). Wildlife trade in the Amazon countries: An analysis of trade in CITES listed species. 


\section{Macrothink

https://www.unep-wcmc.org/resources-and-data/wildlife-trade-in-amazon-countries--an-analy sis-of-trade-in-cites-listed-species. Amazon Regional Program (BMZ/DGIS/GIZ). Cambridge: U N Environment, World Conservation Monitoring Centre, Reino Unido. Link.

Souza, B. C. S., Santos, G. A., \& Campos, R. M. L. (2014). Carne de jacaré: Revisão de literatura. Revista Eletrônica Nutritime.

https://www.nutritime.com.br/arquivos_internos/artigos/ARTIGO277.pdf. Link, 11(6), (pp. 3741-3754).

Tavares, M. C., \& Santos, R. C. (2006). Segmentação: o que antecede à estratégia de mercado alvo. http://www.anpad.org.br/admin/pdf/ema2006-mktc-280.pdf. Retrieved March 042020

Tavares, M. C., Afonso, T., \& Locatelli, R. L. (2011). Segmentação de mercado, diferenciação de produtos e a perspectiva da antropologia do consumo. Revista Gestão \& Tecnologia, Fundação Pedro Leopoldo. Link. http://revistagt.fpl.edu.br/get/article/view/276, 11(1), 106-122.

Valsecchi, J., \& Amaral, P. Vd, V. (2009). Perfil da caça e dos caçadores na reserva de desenvolvimento sustentável Amanã, Amazonas-Brasil. Scientific Magazine UAKARI, 5(2), 33-48. https://doi.org/10.31420/uakari.v5i2.65

Van Vliet, N., Quiceno, M. P., Cruz Antia, D., \& Yagüe, B. (2014). Carne de caça e segurança alimentar na zona da tríplice fronteira amazônica (Colômbia, Peru e Brasil). http://www.cifor.org/publications/pdf_files/Books/BVanVliet1401P.pdf. Centro de Pesquisa Florestal Internacional. Center for International Forestry Research. Bogotá, Colômbia, Brazil. Link.

\section{Copyright Disclaimer}

Copyright for this article is retained by the author(s), with first publication rights granted to the journal.

This is an open-access article distributed under the terms and conditions of the Creative Commons Attribution license (http://creativecommons.org/licenses/by/4.0/). 